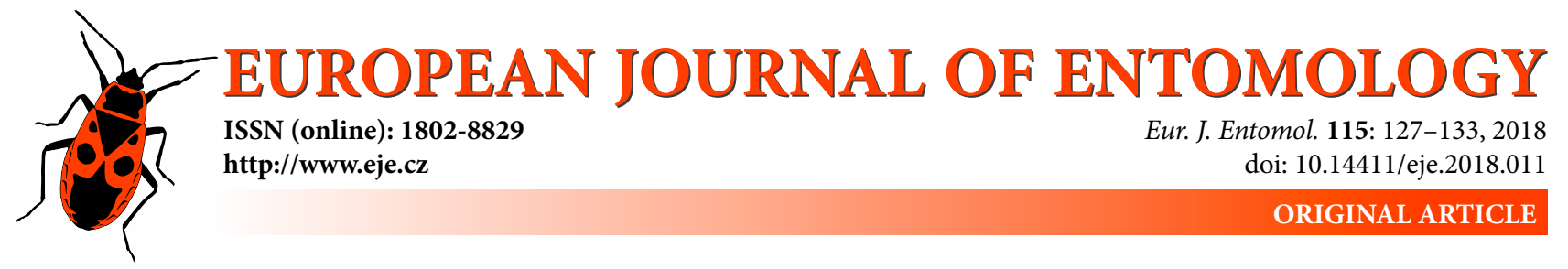

\title{
New fossil genus and species of Sinoalidae (Hemiptera: Cercopoidea) from the Middle to Upper Jurassic deposits in northeastern China
}

\author{
YAN-ZHE FU ${ }^{1,2}$ and DI-YING HUANG ${ }^{1, *}$ \\ ${ }^{1}$ University of Science and Technology of China, Hefei 230026, P.R. China; e-mails: dyhuang@nigpas.ac.cn, yzfu@nigpas.ac.cn \\ ${ }^{2}$ State Key Laboratory of Palaeobiology and Stratigraphy, Nanjing Institute of Geology and Palaeontology, Chinese Academy \\ of Sciences Nanjing, 210008, P.R. China
}

Key words. Hemiptera, Cercopoidea, Sinoalidae, Stictocercopis wuhuaensis, new genus, new species, fossil, Middle to Upper Jurassic, China, Daohugou, Yanliao biota

\begin{abstract}
A new fossil genus and species of Sinoalidae, Stictocercopis wuhuaensis gen. et sp. n., from the Middle to Upper Jurassic Haifanggou Formation at Daohugou, Inner Mongolia, northeastern China is described, illustrated and its systematic position discussed, on the basis of four complete well-preserved specimens. The new genus distinctly differs from other sinoalids in having relatively complex wing venation and tegmen spots. The intra-specific variation in venation is also discussed. The new discovery increases the palaeodiversity of sinoalids in the early assemblage of the Yanliao biota from the Daohugou beds.
\end{abstract}

ZooBank Article LSID: 7F2553EE-E341-43F9-BBB0-526FD518B9AE

\section{INTRODUCTION}

The hemipteran superfamily Cercopoidea Leach, 1815 is the second largest superfamily in the Cicadomorpha, comprising approximately 3000 described species (Hamilton, 2001; Dietrich, 2002). It differs from other extant superfamilies' of Cicadomorpha in having conical and short hind coxa, cylindrical hind tibia with one or more large spines and a body clothed in fine setae (Szwedo et al., 2004; Dietrich, 2005). Adult cercopoids are commonly called froghoppers because they look like tiny frogs and are well adept at jumping (Burrows, 2003).

Cercopoidea is a relatively poorly-known group of $\mathrm{Ci}$ cadomorpha with little knowledge on its origin, evolution, palaeoecology and palaeogeography (Cryan \& Svenson, 2010; Wang et al., 2012). The fossil Cercopoids comprise nearly 40 species attributed to three extinct families (Procercopidae, Sinoalidae and Cercopionidae) known from the Mesozoic to Cenozoic and one extant family (Clastopteridae) from Dominican amber (Poinar et al., 2014; Chen et al., 2015). Cercopoidea was one of the superfamilies derived from the Triassic family Hylicelloidea (Shcherbakov, 1992, 1996). The earliest Cercopoidea are represented by Procercopidae, recorded from the Lower Jurassic in Germany (Handlirsch, 1906). Other Procercopidae are known from the Early Jurassic to Early Cretaceous in Germany,
Russia, Australia, Central Asia, Southeast Asia and China (Evans, 1956; Shcherbakov \& Popov, 2002; Wang \& Zhang, 2009). A small family of the Cercopoidea, named Sinoalidae, established based on fossils from the midJurassic Daohugou beds, is closely related to Procercopidae and shares some synapomorphies with Hylicelloidea (Wang et al., 2012). The diversity of Sinoalidae is relatively low, with approximately eight species attributed to six genera. They include Luanpingia longa (Hong, 1983), Huabeicercopis yangi (Hong, 1983) and Hebeicercopis triangulate (Hong, 1983), which were originally described from the Middle to Upper Jurassic Jiulongshan Formation at Zhouyingzi Village, Luanping County, Chengde city, Hebei Province; Sinoala parallelivena Wang et al., 2012, Jiania crebra Wang et al., 2012, J. gracila Wang et al., 2012, Luanpingia daohugouensis Fu et al., 2017 and Shufania hani Chen et al., 2017, which were described from the Middle to Upper Jurassic Haifanggou Formation at Daohugou Village, Ningcheng County, Chifeng City, Inner Mongolia. Liao et al. (2017) indicate stratigraphic correlations between the Daohugou beds, the type locality of Haifanggou Formation at Beipiao City, West Liaoning Province and the Jiulongshan Formation at Zhouyingzi, Luanping County, Hebei Province based on an analysis of fossil Conchostraca.

\footnotetext{
* Corresponding author; e-mail: dyhuang@nigpas.ac.cn
} 
Herein we describe a new fossil genus and species of Sinoalidae, Stictocercopis wuhuaensis gen. et sp. n. from the Middle to Upper Jurassic Haifanggou Formation at Daohugou, Inner Mongolia, northeastern China.

\section{MATERIAL AND METHODS}

The new species is erected on the basis of four specimens, two of which are complete with parts and counterparts, and the two remaining specimens are nearly complete without counterparts. All these specimens are dorso-ventrally compressed and display fine details including antennae, ocelli, ornaments on tegmen, hind wings, legs and terminals. They were collected at Xiayingzi, the deposits at which occur below layers with Conchostraca in the Daohugou beds (for the map of fossil layers that yielded new species and locations near Daohugou, see Jiang et al., 2016). They are preserved in grey or dark greyish fine laminated tuffaceous shale. All these fossils come from the Daohugou beds in the Haifanggou Formation with a geological age close to the Middle to Upper Jurassic boundary (163.5 Ma) (Huang, 2016).

All specimens were carefully prepared using a sharp knife, and studied under a Leica MZ16A dissecting microscope. Line drawings were prepared using a binocular Olympus SZX7 microscope and a camera lucida. Photographs were taken using a digital camera attached to a Zeiss Discovery V20 microscope, and some were moistened with $70 \%$ ethanol to show fine details. Photomicrographs of general habitus were taken using a Canon EOS 5D Mark II camera with a Canon $100 \mathrm{~mm}$ macro lens. Micro surface information was obtained under the Low Vacuum mode (100 Pa in sample chamber) of a Hitachi SU-3500 SEM with the accelerating voltage set at $20.0 \mathrm{KV}$. The material studied here is deposited at the Nanjing Institute of Geology and Palaeontology, Chinese Academy of Sciences, Nanjing, China.

The venation terminologies used herein follow the interpretations of wing venation for all Paraneoptera (Nel et al., 2012) with slight modifications and reference to the standardized terminology of the forewing venation in Fulgoromorpha (Bourgoin et al., 2015).

\section{SYSTEMATIC PALEONTOLOGY}

Order Hemiptera Linnaeus, 1758

Suborder Cicadomorpha Evans, 1946

Superfamily Cercopidea Leach, 1815

Family Sinoalidae Wang \& Szwedo, 2012

Genus Stictocercopis gen. $\mathbf{n}$.

ZooBank taxon LSID:

EF6C2983-82BA-4AA8-9BF9-646307B45D4D

Type species. Stictocercopis wuhuaensis sp. n.

Etymology. The generic name is a combination of the Greek word "stiktos" $(\sigma \tau 1 \kappa \tau$ ó $\varsigma)=$ spotted, which indicates the spotted tegmen and the known genus Cercopis. Gender: masculine.

Diagnosis. The new genus distinctly differs from other known genera in the following characters: antenna setiform, flagellum bearing at least eight elongate segments; tegmen dotted with elliptical spots on veins; RA with 3-4 branches; RP with 2 branches; MP with 5 terminals; hind wings, MP with 2 branches, branching at the same level of $\mathrm{CuA}$; hind tibia armed with two rows of a total of 5-7 large lateral spines.

\section{Stictocercopis wuhuaensis sp. $\mathbf{n}$.}

(Figs 1-5)

ZooBank taxon LSID:

7B5047DD-EE8A-4741-9D1E-502CC94A127F

Etymology. The epithet "wuhuaensis" indicates the locality, Wuhua Township, where the specimens were collected.

Material. Holotype, NIGP166867 (a, b), a well-preserved adult male in dorsal-ventral aspect with fore and hind wings extended. Paratype includes three males, NIGP166868, NIGP166869 and NIGP167803, nearly complete in dorsal-ventral aspect with fore and hind wings extended.

Type locality, formation and age. Daohugou Village, Wuhua Township, Ningcheng County, Chifeng City, Inner Mongolia, China; Haifanggou Formation; Middle to Upper Jurassic (near the boundary of Callovian and Oxfordian).

Diagnosis. As for genus (vide supra).

Description. Total length $12.7 \mathrm{~mm}$ in holotype (NIGP166867), $12.4 \mathrm{~mm}$ in NIGP166868, $12.5 \mathrm{~mm}$ in NIGP166869 and NIGP167803; tegmen $10.2 \mathrm{~mm}$ long and $3.2 \mathrm{~mm}$ wide in the holotype (NIGP166867), $9.8 \mathrm{~mm}$ long and $3.1 \mathrm{~mm}$ wide in NIGP166868, $9.8 \mathrm{~mm}$ long and $3.0 \mathrm{~mm}$ wide in NIGP167803, and tegmen deformed in NIGP166869. The following measurements are based on the holotype.

Head not flattened, rounded apically (Figs 1D, 2B); compound eyes large, located laterally, nearly globose; postclypeus swollen, with transverse impressions, $0.95 \mathrm{~mm}$ long and $0.44 \mathrm{~mm}$ wide, in facial portion with median concavity extending slightly towards the crown; anteclypeus less swollen, nearly half the length of postclypeus, and clypellus is triangularly elongated; three ocelli present, ocellar triangle distinct (Fig. 2B); loral plates wider than maxillary plate, crescent-like in ventral view, $1.0 \mathrm{~mm}$ long and 0.3 mm wide; maxillary plate subquadrate in cross-section; antennae setiform, inserted in deep cavities between the eyes, about $1.3 \mathrm{~mm}$ long, flagellum with at least eight elongate segments; scape large but short, pedicel thinner and longer than scape, flagellomeres 1 to 8 becoming gradually thinner and shorter (Figs 1E, F); rostrum $2.3 \mathrm{~mm}$ long, reaches base of hind coxae.

Pronotum irregularly hexagonal, partly punctate (Fig. 1D), about 1.5-1.7 times as wide as head; posterior angles rounded, posterior edge concave medially; mesonotum with scutellum triangular, $2.9 \mathrm{~mm}$ long and $2.0 \mathrm{~mm}$ wide.

Tegmen dotted with elliptical spots on veins, with length/ width ratio about 3.1 (Figs $1 \mathrm{G}, 2 \mathrm{G}$ ), punctate (less punctate near apex), appendix very narrow, costal margin thickened, slightly arched at base; posterior margin straight; apical margin rounded; basal cell about 0.24 times as long as tegmen; branch ScP + RA nearly 1.8 times longer than stem $\mathrm{ScP}+\mathrm{R}$; ScP $+\mathrm{R}$ branching into $\mathrm{ScP}+\mathrm{RA}$ and $\mathrm{RP}$ at 0.47 length from base of tegmen; stem $\mathrm{ScP}+\mathrm{RA}$ branching into $\mathrm{ScP}$ and RA after vein MP branching at 0.72 length from base of tegmen; RA with 3-4 branches, connected with RP by cross vein ir at 0.83 length measured from base of tegmen; RP with 2 branches, connected with $\mathrm{MP}_{1+2}$ by r-m at 0.77 tegmen length; MP branching into $\mathrm{MP}_{1+2}$ and $\mathrm{MP}_{3+4}$ distinctly basal of $\mathrm{CuA}$ branching at 0.64 tegmen length, 

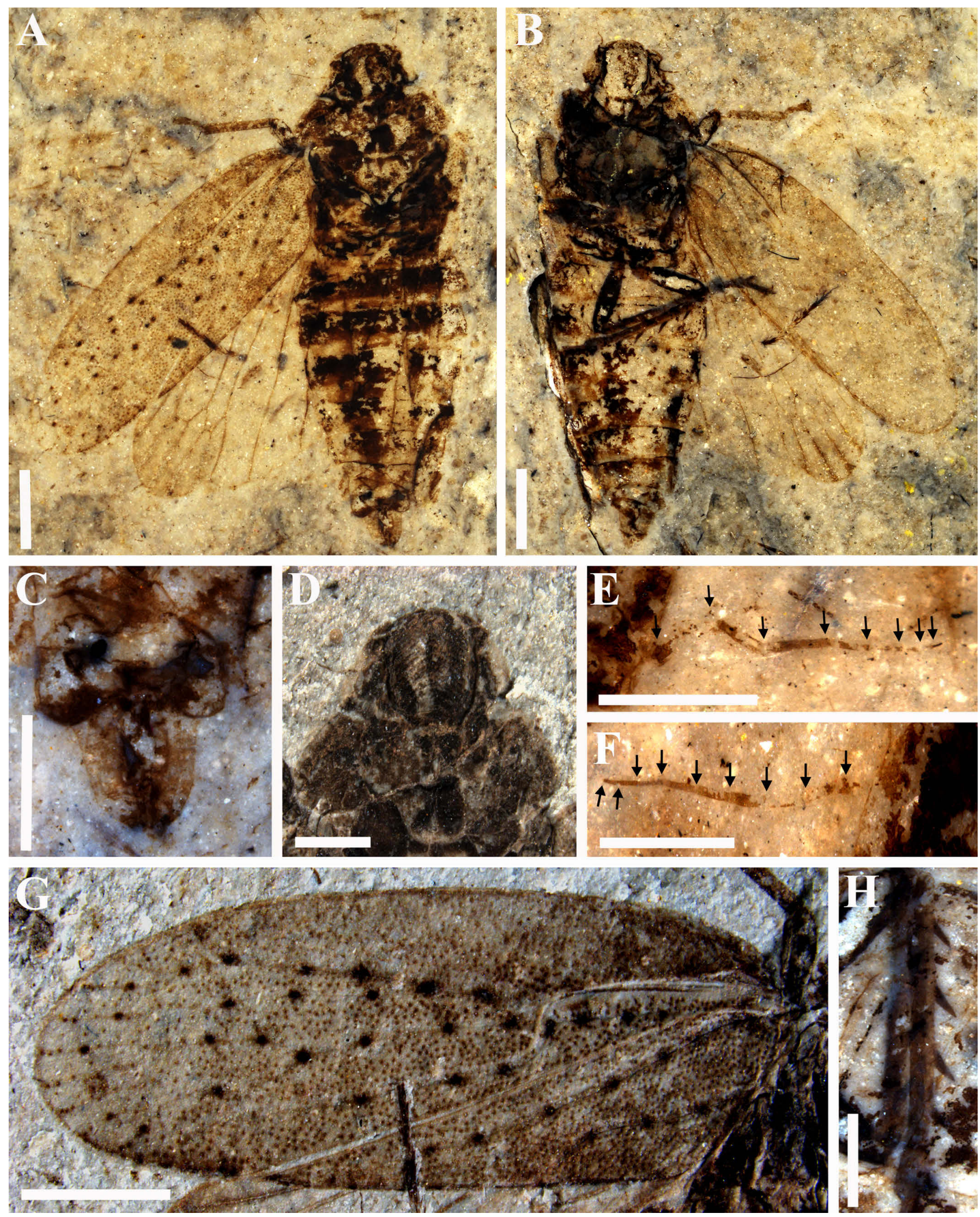

Fig. 1. Male holotype of Stictocercopis wuhuaensis gen. et sp. n. from the Middle to Upper Jurassic Haifanggou Formation at Daohuguo. A - counterpart (NIGP166867b), general habitus with dorsal structures; B - part (NIGP166867a), general habitus with ventral structures; $\mathrm{C}$ - enlargements of A, showing the details of genitals; D - showing the details of head and pronotum; $E$ and $F$ - enlargements of A, showing the details of left antenna with nine elongate segments; $G$ - showing the details of right tegmen; $H$ - enlargements of $B$, showing the details of hind tibia. A-C, E, F, H moistened with $70 \%$ ethanol. Scale bars: $2 \mathrm{~mm}(\mathrm{~A}, \mathrm{~B}, \mathrm{G}) ; 1 \mathrm{~mm}(\mathrm{C}-\mathrm{F}, \mathrm{H})$.

with 5 terminals, slightly contorted near tegmen apex; stem $\mathrm{MP}_{1+2}$ branching into $\mathrm{MP}_{1}$ and $\mathrm{MP}_{2}$ at the same level of r-m; im slant, connecting $\mathrm{MP}_{2}$ and $\mathrm{MP}_{3}$ or connecting
$\mathrm{MP}_{2}$ and $\mathrm{M}_{3+4}$ at the dividing point; $\mathrm{MP}_{4}$ bifurcating $\mathrm{MP}_{4 \mathrm{a}}$ and $\mathrm{MP}_{4 \mathrm{~b}}$ halfway; $\mathrm{C} 3$ developed, with length/width ratio about 3.5; CuA curved anteriorly, bifurcating into branch- 

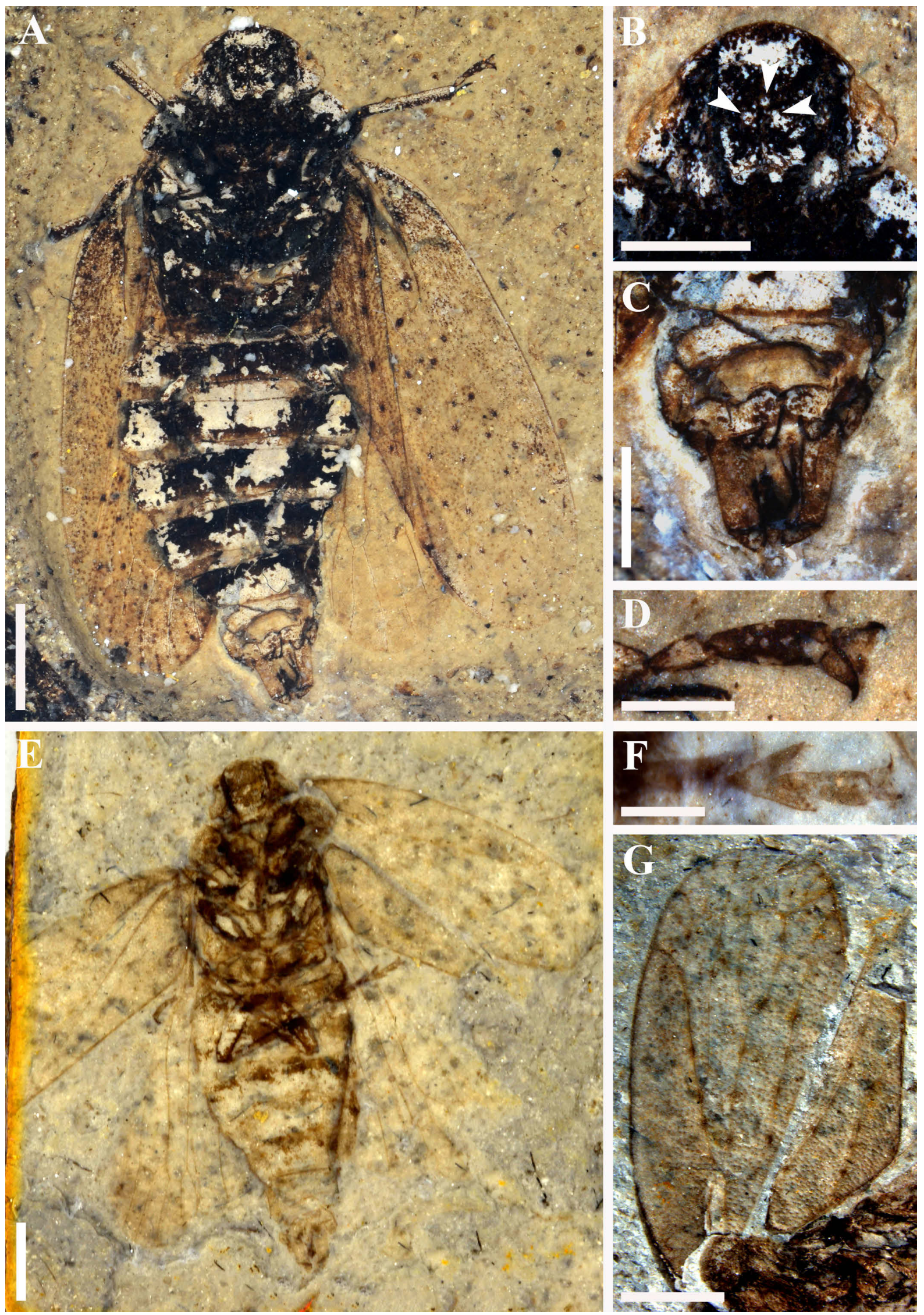

Fig. 2. Paratypes, males of Stictocercopis wuhuaensis gen. et sp. n., from the Middle to Upper Jurassic at Daohuguo. A - NIGP166868, general habitus in ventral view; $B$ - enlargement of $A$, showing the details of head structure with three ocelli (white arrows); $C$ - enlargement of A, showing the details of genitals; D - enlargement of A, showing the details of fore tarsi and claws; E - NIGP166869, general habitus in ventral view; $F$ - enlargement of $E$, showing the details of hind tarsi; $G$ - enlargement of $E$, showing the details of right tegmen (deformed). A - F moistened with 70\% ethanol. Scale bars: $2 \mathrm{~mm}$ (A, E, G); $1 \mathrm{~mm}$ (B, C); $0.5 \mathrm{~mm}$ (D, F). 

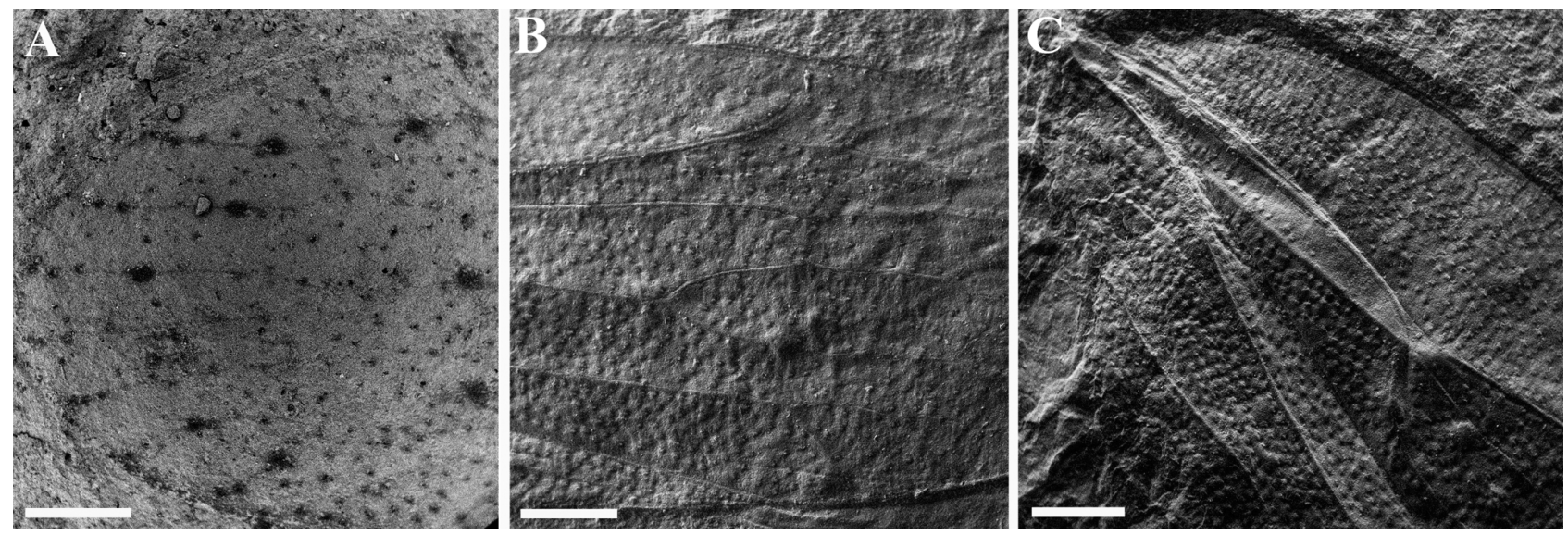

Fig. 3. Scanning electron microscope (SEM) photomicrograph of Stictocercopis wuhuaensis gen. et sp. n. A - holotype (NIGP166867b), showing the micro surface structures at the apex of right tegmen; B - paratype (NIGP166868), showing the micro surface structures on the right tegmen; $\mathrm{C}$ - paratype (NIGP166868), showing the micro surface structures on the right tegmen. Scale bars: $0.5 \mathrm{~mm}$.
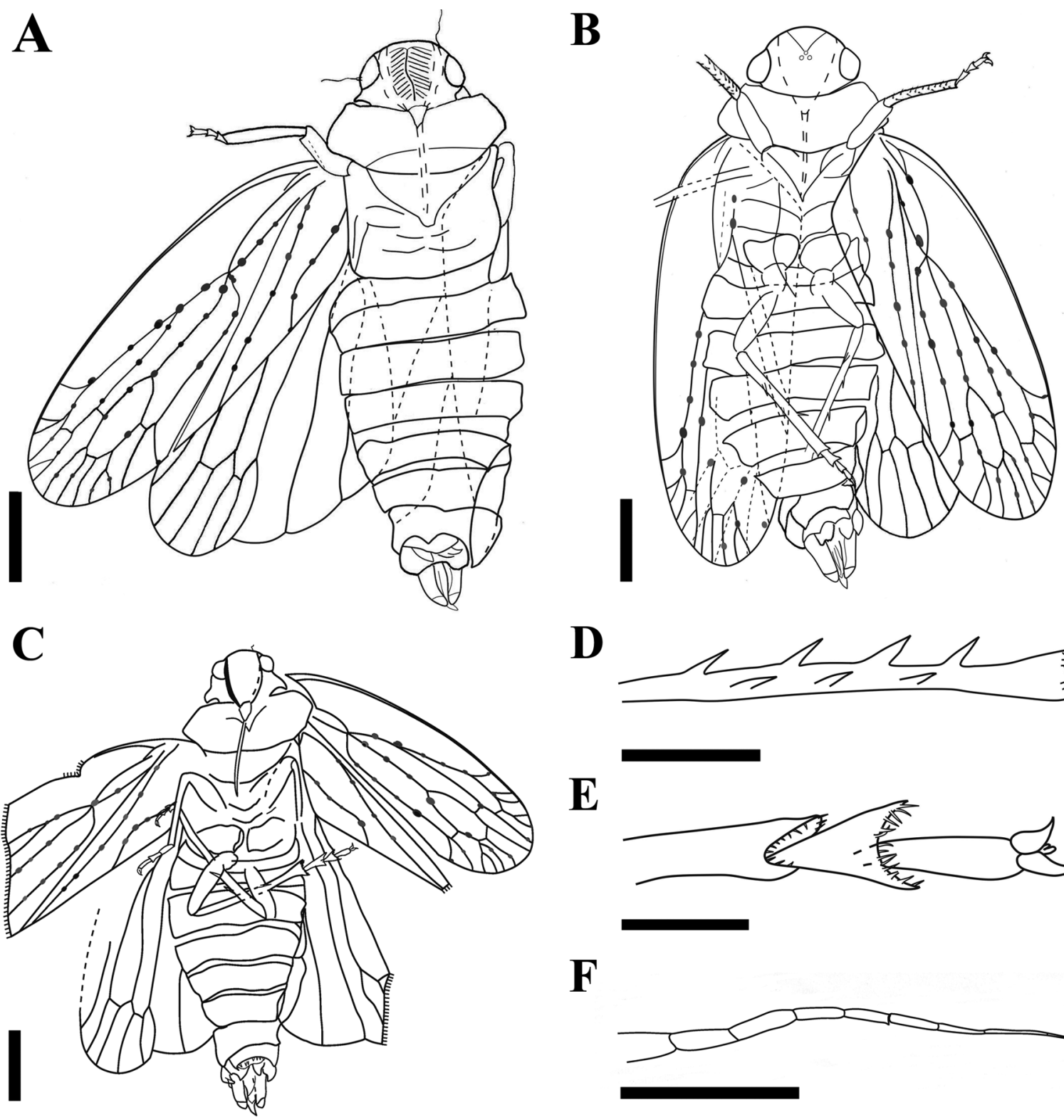

D

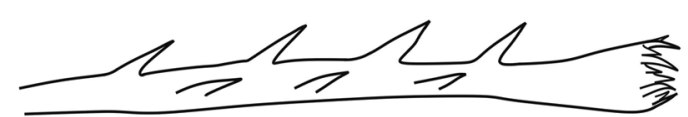

$\mathbf{E}$

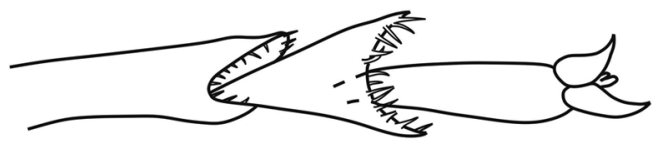

$\mathbf{F}$

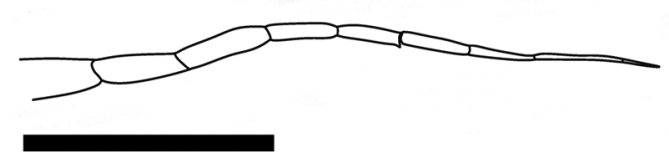

Fig. 4. Line drawings of Stictocercopis wuhuaensis gen. et sp. n. A-general habitus of the holotype (NIGP166867b); B - general habitus of the paratype (NIGP166868); C - general habitus of the paratype (NIGP166869); D - hind tibia of the holotype (NIGP166867); E - hind tarsi of the paratype (NIGP166869); F - antenna of the holotype (NIGP166867b). Scale bars: $2 \mathrm{~mm}(\mathrm{~A}-\mathrm{C}) ; 1 \mathrm{~mm}$ (D); $0.5 \mathrm{~mm}$ (E, F). 


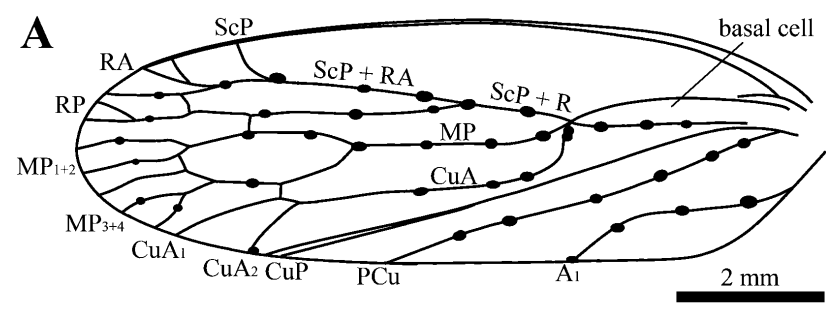

B

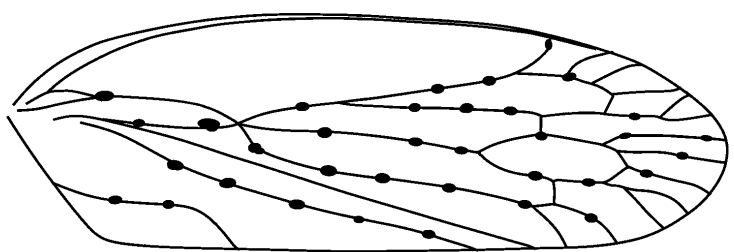

C

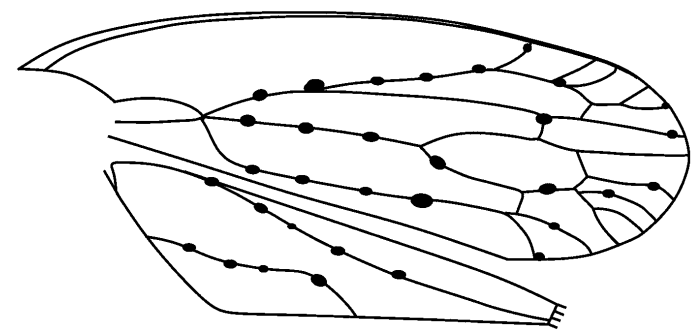

D

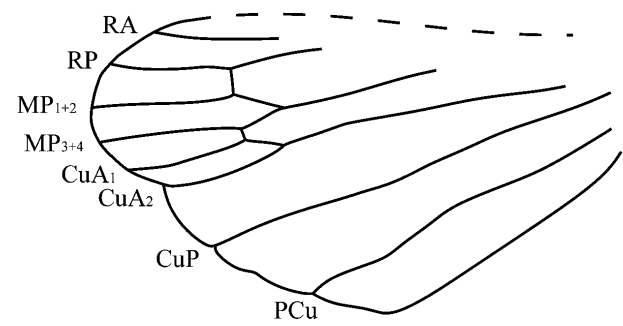

Fig. 5. Line drawings of Stictocercopis wuhuaensis gen. et $\mathrm{sp} . \mathrm{n}$. A - right tegmen of the holotype (NIGP166867b); B - right tegmen of the paratype (NIGP166868); C - right tegmen of the paratype (NIGP166869); D - hind wings of the holotype (NIGP166867b). Scale bars: $2 \mathrm{~mm}$.

es $\mathrm{CuA}_{1}$ and $\mathrm{CuA}_{2}$ distinctly after MP branching; branch $\mathrm{CuA}_{1}$ about 1.7 times longer than $\mathrm{CuA}_{2} ; \mathrm{m}$-cu after $\mathrm{CuA}$ branching and connected with $\mathrm{CuA}_{1} ; \mathrm{CuP}$ almost straight; $\mathrm{PCu}$ slightly distorted; $\mathrm{A}_{1}$ sinuous. Hind wings partly visible, subtriangular, distinctly shorter than tegmen, without peripheral membrane; MP with 2 branches, branching into $\mathrm{MP}_{1+2}$ and $\mathrm{MP}_{3+4}$ at same level as $\mathrm{CuA}$ branches; $\mathrm{CuA}$ with 2 branches; cross vein $\mathrm{r}-\mathrm{m}$ at the same level of $\mathrm{m}$-cu.

Fore femur robust, approximately $1.2 \mathrm{~mm}$ long and 0.5 $\mathrm{mm}$ wide; fore tibia circa 1.5 times longer than femur; fore tarsus with three tarsomeres (Fig. 2D), circa $0.9 \mathrm{~mm}$ long, tarsal claws distinct; middle femur approximately $1.3 \mathrm{~mm}$ long, and more slender than fore femur; middle tibia longer than fore tibia; hind coxae enlarged and transverse, circa $1.4 \mathrm{~mm}$ long and $0.9 \mathrm{~mm}$ wide; hind trochanter about 0.7 $\mathrm{mm}$ long; hind femur circa $1.6 \mathrm{~mm}$ long and $0.4 \mathrm{~mm}$ wide; hind tibia $3.5 \mathrm{~mm}$ long, nearly twice as long as fore tibia, with two rows of large lateral spines (Fig. 1H), one row with 3-4 spines and the other with 2-3 spines, hind tibia slightly widened apically, armed with two rows of at least 9 apical tiny teeth with subapical setae; hind tarsus nearly twice as long as fore tarsus, with three tarsomeres (Fig. 2F); basal tarsomere as long as third tarsomere and longer than second tarsomere, armed with a row of apical teeth; apex of second tarsomere armed with at least 14 apical teeth; tarsal claws short and robust, sharp apically; arolium present.

Abdominal segments III to VIII are progressively shorter, sternites strongly sclerotized; pygofer short, lunate-like in ventral view; genital valve relatively wide, fused with pygofer; genital plates separated, subtriangular, wide and robust, partly fused with genital valve; genital style sclerotized apically; anal style elongate, distinctly exceeding apex of pygofer (Figs 1C, 2C).

\section{DISCUSSION}

The new genus can be attributed to Sinoalidae based on the following apomorphic characters: tegmen partly punctate, costal margin thickened, almost extending to apex of tegmen; MP branching into $\mathrm{M}_{1+2}$ and $\mathrm{M}_{3+4}$ distinctly basad of bifurcation of $\mathrm{CuA}$; cross vein im and m-cu present; hind wings without peripheral membrane; hind tibia with two rows of a total of 5-7 lateral spines.

The new genus distinctly differs from the other known genera in the presence of tegminal spots and a relatively complex wing venation on both tegmen and hind wings as follows. (1) RA with 3-4 branches, RP with 2 branches, and MP branching with 5 terminals in new genus in contrast to RA and RP with single branch, MP with two terminals in other genera. (2) MP of hind wings with 2 branches in new genus in contrast to a single branch in other genera. (3) The cross vein r-m in hind wings at the same level as $\mathrm{m}$-cu in new genus in contrast to $\mathrm{m}$-cu earlier than $\mathrm{r}-\mathrm{m}$ in Heibeicercopis and Sinoala. (4) Antennal flagellum has eight segments in the new genera in contrast to at least six segments visible in Sinoala.

The tegminal venation of Stictocercopis wuhuaensis is variable. For example, RA with 3 branches in the holotype (NIGP166867) and paratype (NIGP166868), but with 4 branches in another paratype (NIGP166869); cross vein $\mathrm{r}-\mathrm{m}$ basal of m-cu in NIGP166868, but distal of m-cu in NIGP166867 and NIGP166869; cross vein im connects $\mathrm{MP}_{2}$ and $\mathrm{MP}_{3}$ in NIGP166867 and NIGP166868, but connects $\mathrm{M}_{2}$ and the dividing point of $\mathrm{M}_{3+4}$ in NIGP166869. These specimens were collected in the same horizon and locality, of similar size, length/width ratio of tegmen and body structures, and the variation is limited to terminal branches and connecting position of cross veins. Therefore, these specimens could be attributed to the same species.

To date, the Sinoalidae includes seven genera only from the Middle to Upper Jurassic in northeastern China. The new species provides new insights into the biodiversity of Mesozoic Sinoalidae and increases our understanding of the origin and evolution of the family.

ACKNOWLEDGEMENTS. This work was funded by the Ministry of Science and Technology (2016YFC0600406), the Strategic Priority Research Program of the Chinese Academy of Sciences (XDB18000000 and XDPB05), and the National Natural Science 
Foundation of China (41688103). This study is a contribution to UNESCO-IUGS IGCP Project 632.

\section{REFERENCES}

ANUfriev G.A. 1972: Revision of froghoppers from the genus Sinophora Melichar, 1902 (Homoptera, Aphrophoridae). - J. Nat. Hist 6: 385-394.

Bourgoin T., Wang R., Asche M., Hoch H., Soulier-Perkins A., Stroinski A., YAP S. \& SzWEDO J. 2015: From micropterism to hyperpterism: recognition strategy and standardized homology-driven terminology of the forewing venation patterns in planthoppers (Hemiptera: Fulgoromorpha). - Zoomorphology 134: 63-77.

Burrows M. 2003: Biomechanics: froghopper insects leap to new heights. - Nature 424: 509.

Chen J., Zhang H.C, Wang B., Zheng X.T. \& Wang X.L. 2015: High variability in tegminal venation of primitive cercopoids (Hemiptera: Cicadomorpha), as implied by the new discovery of fossils from the Middle Jurassic of China. - Entomol. Sci. 18: $147-152$.

Chen J., Zheng Y., Wei G.J. \& Wang X.L. 2017: New data on Jurassic Sinoalidae from northeastern China (Insecta, Hemiptera). - J. Paleontol. 91: 994-1000.

Chou I., Yuan F. \& Liang A.P. 1986: The systematics and phylogeny of the genus Sinophara Melichar (Homoptera: Aphrophoridae). - Entomotaxonomia 8: 97-120 [in Chinese, English abstr.].

Cryan J.R. \& Svenson G.J. 2010: Family-level relationships of the spittlebugs and froghoppers (Hemiptera: Cicadomorpha: Cercopoidea). - Syst. Entomol. 35: 393-415.

Dietrich C.H. 2002: Evolution of Cicadomorpha (Insecta, Hemiptera). - Denisia 4: 155-170.

DiETRICH C.H. 2005: Keys to the families of Cicadomorpha and subfamilies and tribes of Cicadellidae (Hemiptera: Auchenorrhyncha). - Fla Entomol. 88: 502-517.

Evans J.W. 1946: A natural classification of leaf-hoppers (Homoptera, Jassoidea). Part 1. External morphology and systematic position. - Trans. R. Entomol. Soc. Lond. 96: 47-60.

Evans J.W. 1956: Palaeozoic and Mesozoic Hemiptera (Insecta). - Aust. J. Zool. 4: 164-258.

Fu Y.Z., CAI C.Y. \& Huang D.Y. 2017: A new fossil sinoalid species from the Middle Jurassic Daohugou beds (Insecta: Hemiptera: Cercopoidea). - Alcheringa 42: 94-100.

Handlirsch A. 1906-1908: Die Fossilen Insekten und die Phylogenie der rezenten Formen: ein Handbuch für Paläontologen und Zoologen. Engelmann, Leipzig, 1430 pp.

HamiLton K.G.A. 2001: A new family of froghoppers from the American tropics (Hemiptera: Cercopoidea: Epipygidae). Biodiversity 2: 15-21.

Hong Y.C. 1983: Middle Jurassic Fossil Insects in North China. Geological Publishing House, Beijing, 223 pp. [in Chinese].
Huang D.Y. 2015: Yanliao Biota and Yanshan movement. - Acta Palaeontol. Sin. 54: 501-546 [in Chinese, English abstr.].

Huang D.Y. 2016: The Daohugou Biota. Shanghai scientific and technical publishers, Shanghai, $332 \mathrm{pp}$. [in Chinese].

Jiang J.Q., Cai C.Y. \& Huang D.Y. 2016: Progonocimicids (Hemiptera, Coleorrhyncha) from the Middle Jurassic Haifanggou Formation, western Liaoning, northeast China support stratigraphic correlation with the Daohugou beds. - Alcheringa 40: 53-61.

LeAch W.E. 1815: Entomology. In Brewster D. (ed.): The Edinburgh Encyclopaedia, Vol. 9, Part 1. William Blackburn, Edinburgh, $384 \mathrm{pp}$.

LinNaEus C. 1758: Systema naturae per regna tria naturae, secundum classes, ordinus, genera, species, cum characteribus, differentiis, synonymis, locis. 10th ed., Vol. 1. Holmiae Salvii, $824 \mathrm{pp}$.

Liao H., Shen Y.B. \& Huang D.Y. 2017: Conchostracans of the Middle-Late Jurassic Daohugou and Linglongta beds in NE China. - Palaeoworld 26: 317-330.

Nel A., Prokop J., Nel P., Grandcolas P., Huang D. Y, Roques P., Guilbert E., Dostál O. \& Szwedo J. 2012: Traits and evolution of wing venation pattern in paraneopteran insects. $-J$. Morphol. 273: 480-506.

Poinar G.O.J, Hamilton K.G.A. \& Brown A.E. 2014: Prisciba, n. gen. and two new species of fossil froghoppers (Hemiptera: Cercopoidea: Clastopteridae) in Dominican amber. - Hist. Biol. 26: 1-5.

ShCherbakov D.E. 1992: The earliest leafhoppers (Hemiptera: Karajassidae n. fam.) from the Jurassic of Karatau. $-N$. $J b$. Geol. Palaeont. Mh. 1: 39-51 [in German].

ShCherbakov D.E. 1996: Origin and evolution of the Auchenorrhyncha as shown in the fossil record. In Schaefer C.W. (ed.): Studies on Hemipteran Phylogeny. Entomological Society of America, Lanham, pp. 31-45.

ShCherbakov D.E. \& Popov Y.A. 2002: Superorder Cimicidea Laicharting, 1781, order Hemiptera Linné, 1758. The bugs, cicadas, plantlice, scale insects, etc. In Rasnitsyn A.P. \& Quicke D.L.J. (eds): History of Insects. Kluwer, Dordrecht, pp. 152155.

Szwedo J., Bourgoin T. \& Lefebvre F. 2004: Fossil planthoppers (Hemiptera: Fulgoromorpha) of the world. An Annotated Catalogue with Notes on Hemiptera Classification. Studio 1, Warszawa, 199 pp.

Wang B. \& Zhang H.C. 2009: A remarkable new genus of Procercopidae (Hemiptera: Cercopoidea) from the Middle Jurassic of China. - C. R. Palevol. 8: 389-394.

Wang B., Szwedo J. \& Zhang H. 2012: New Jurassic Cercopoidea from China and their evolutionary significance (Insecta: Hemiptera). - Palaeontology 55: 1223-1243.

Received December 4, 2017; revised and accepted February 28, 2018 Published online March 26, 2018 